\title{
The importance of a well-structured pancreatic screening program for familial and hereditary pancreatic cancer
}

\author{
Hans F. A. Vasen ${ }^{1}$ \\ Published online: 4 December 2017 \\ ๑) Springer Science+Business Media B.V., part of Springer Nature 2017
}

In this issue of Familial Cancer, Barnes et al. describe a screening program for individuals at high risk of developing pancreatic ductal adenocarcinoma (PDAC) [1]. Approximately $3-10 \%$ of all patients with PDAC have a positive family history for this cancer [2], and $4 \%$ have an underlying gene defect, with ATM, BRCA1 \& BRCA2, and PALB2 being the most commonly effected genes [3-6] (Table 1). Familial pancreatic cancer (FPC) is defined by the occurrence of PDAC in two or more first-degree relatives, in the absence of an underlying gene defect [2]. The risk of developing PDAC depends on the particular gene defect (Table 1) [7-12], and in FPC, on the number of first-degree family members with PDAC.

Since the first report of pancreatic screening of high-risk individuals by Brentnall et al., several other screening studies have been completed [13]. Most studies involved FPC families, while a few included carriers of a PDAC-associated gene defect $[12,14-16]$. The screening protocols used in these studies varied widely, including MRI only, both MRI and endoscopic ultrasound (EUS), or MRI with optional EUS.

Barnes et al. are to be commended on the development of a solid and well-structured clinical program [1]. Adopting a multidisciplinary approach, the program uses gene panels, appropriate genetic counseling, and a protocol that includes annual 3.0 T MRI and additional EUS in case of abnormalities. All results are discussed at a multidisciplinary PDAC conference. Five years into the program, a total of 75 individuals have participated, including $42(56 \%)$ carriers of a PDAC-associated gene defect and $35(44 \%)$ individuals with FPC. One cholangiocarcinoma was detected and cystic lesions were observed in $40 \%$ of cases, which is in agreement with previous studies.

Hans F. A. Vasen

hfavasen@stoet.nl

1 Department of Gastroenterology and Hepatology, Leiden University Medical Centre, Leiden, The Netherlands
At a consensus meeting of the International CAPS (Cancer of the Pancreas Screening) consortium in 2013 [17], detailed criteria were developed for the selection of individuals eligible for screening of the pancreas. In general, a lifetime risk of 5\% or more was considered an indication for screening. Publication of the guidelines has increased interest in these high-risk groups and enhanced the implementation of screening worldwide. However, an important remaining issue is that the value of the proposed screening programs has not yet been proven. These programs are therefore only suitable in a research setting and in specialized centers with high-volume pancreatic surgery and welldefined screening protocols. The protocol developed by Barnes et al. is a good example of a high-quality program [1].

The choice for (3.0 T) MRI as the primary screening tool, followed by EUS in case of abnormalities, seems appropriate, although the optimal screening approach still needs to be defined. A study by Harinck et al. showed that the results of MRI and EUS are complementary, MRI showing greater sensitivity in the identification of cystic lesions and EUS in the detection of solid lesions [18]. The program described by Barnes and colleagues also included the use of tumor markers (CEA, CA19.9). Although both markers have proven value in the follow-up of various cancers after treatment, the value of these markers for screening purposes is unknown. One major drawback is that when elevated levels of a marker are identified without evidence of abnormalities, as reported in a few cases in this study, severe anxiety may result. The possibility of false positive findings should therefore be discussed with patients beforehand.

Another major question is which individuals to screen? Pandharipande et al. developed a simulation model for PDAC that can be used to evaluate the effect of screening of specific high-risk groups [19]. Using this model, they showed an increased life expectancy for individuals with a BRCA1/BRCA2 mutation and a strong family history for PDAC. In contrast, in the overall cohort of 
Table 1 Estimated frequency of germline gene defects in sporadic and FPC and reported risk of PDAC [3-12]

\begin{tabular}{llll}
\hline Gene defect & $\begin{array}{l}\text { Frequency in } \\
\text { sporadic PDAC } \\
(\%)\end{array}$ & $\begin{array}{l}\text { Frequency in } \\
\text { familial PDAC } \\
(\%)\end{array}$ & $\begin{array}{l}\text { Estimated } \\
\text { lifetime risk of } \\
\text { PDAC }\end{array}$ \\
\hline BRCA2 & 1.4 & $0.8-3.7$ & $<5 \%$ \\
ATM & 1.2 & $2.6-3.2$ & Unknown \\
BRCA1 & 0.4 & $0.7-1.2$ & $\sim 2 \%$ \\
MMR-genes & 0.1 & 0.7 & $6 \%($ MSH2) \\
PALB2 & 0.2 & $0.3-0.8$ & Unknown \\
CDKN2A & 0.1 & $0.7-2.5$ & $15-25 \%$ \\
\hline
\end{tabular}

$B R C A 1 / B R C A 2$ carriers with and without a family history of PDAC, life expectancy was reduced. This was attributed to the increased discovery of insignificant lesions and subsequent surgical intervention. The authors concluded that only those individuals with a sufficiently increased risk may derive benefit from screening.

In view of this conclusion, it is important to recognize that the risk of developing PDAC for most groups of mutation carriers, including those in the Barnes's study, is still unknown (Table 1). A recent study on the frequency and type of gene defects in a large series of sporadic PDAC reported that family history is inconclusive in most patients with an identified gene defect [3] Based on this observation, the authors concluded that routine gene testing of patients with newly diagnosed pancreatic cancer may yield significant clinical benefits for patients and family members. On the other hand, this approach may lead to identification of many individuals with an unknown risk of PDAC and may thus cause considerable anxiety, especially in view of the unproven value of screening. Implementation of routine testing of gene panels in sporadic PDAC may therefore require further consideration.

The prognosis of PDAC is still very poor, and has seen no improvement over the last 50 years. The only path to a better prognosis is early detection of precursor lesions or early stage cancer, particularly by offering screening to individuals at high risk. Despite the many difficulties involved in the screening of these high-risk groups, if we wish to make progress we should continue screening but under strict preconditions. The first step is the development of an appropriate, well-structured surveillance program as presented by Barnes et al. in this issue.

\section{References}

1. Barnes CA, Krzywda E, Lahiff S, McDowell D, Christians KK, Knechtges P et al (2017) Development of a high risk pancreatic screening clinic using 3.0 T MRI. Fam Cancer. https://doi. org/10.1007/s10689-017-0057-z.
2. Bartsch DK, Gress TM, Langer P (2012) Familial pancreatic cancer-current knowledge. Nat Rev Gastroenterol Hepatol 9(8):445-453

3. Shindo K, Yu J, Suenaga M, Fesharakizadeh S, Cho C, Macgregor-Das A et al (2017) Deleterious germline mutations in patients with apparently sporadic pancreatic adenocarcinoma. J Clin Oncol 35(30):3382-3390

4. Zhen DB, Rabe KG, Gallinger S, Syngal S, Schwartz AG, Goggins MG et al (2015) BRCA1, BRCA2, PALB2, and CDKN2A mutations in familial pancreatic cancer: a PACGENE study. Genet Med 17(7):569-577

5. Roberts NJ, Norris AL, Petersen GM, Bondy ML, Brand R, Gallinger $S$ et al (2016) Whole genome sequencing defines the genetic heterogeneity of familial pancreatic cancer. Cancer Discov 6(2):166-175

6. Chaffee KG, Oberg AL, McWilliams RR, Majithia N, Allen BA, Kidd J et al (2017) Prevalence of germ-line mutations in cancer genes among pancreatic cancer patients with a positive family history. Genet Med. https://doi.org/10.1038/gim.2017.85

7. de Snoo FA, Bishop DT, Bergman W, van Leeuwen I, van der Drift C, van Nieuwpoort FA et al (2008) Increased risk of cancer other than melanoma in CDKN2A founder mutation (p16-Leiden)-positive melanoma families. Clin Cancer Res 14(21):7151-7157

8. Thompson D, Easton DF, Breast Cancer Linkage C (2002) Cancer Incidence in BRCA1 mutation carriers. J Natl Cancer Inst 94(18):1358-1365

9. van Asperen CJ, Brohet RM, Meijers-Heijboer EJ, Hoogerbrugge N, Verhoef S, Vasen HF et al (2005) Cancer risks in BRCA2 families: estimates for sites other than breast and ovary. J Med Genet 42(9):711-719

10. Moller P, Seppala TT, Bernstein I, Holinski-Feder E, Sala P, Gareth Evans D et al (2017) Cancer risk and survival in path_ MMR carriers by gene and gender up to 75 years of age: a report from the Prospective Lynch Syndrome Database. Gut. https:// doi.org/10.1136/gutjnl-2017-314057

11. Breast Cancer Linkage C (1999) Cancer risks in BRCA2 mutation carriers. J Natl Cancer Inst 91(15):1310-1316

12. Vasen H, Ibrahim I, Ponce CG, Slater EP, Matthai E, Carrato A et al (2016) Benefit of surveillance for pancreatic cancer in high-risk individuals: outcome of long-term prospective followup studies from three european expert centers. J Clin Oncol 34(17):2010-2019

13. Brentnall TA, Bronner MP, Byrd DR, Haggitt RC, Kimmey MB (1999) Early diagnosis and treatment of pancreatic dysplasia in patients with a family history of pancreatic cancer. Ann Intern Med 131(4):247-255

14. Canto MI, Hruban RH, Fishman EK, Kamel IR, Schulick R, Zhang Z et al (2012) Frequent detection of pancreatic lesions in asymptomatic high-risk individuals. Gastroenterology 142(4):796-804 (quiz e14-5)

15. Langer P, Kann PH, Fendrich V, Habbe N, Schneider M, Sina $M$ et al (2009) Five years of prospective screening of high-risk individuals from families with familial pancreatic cancer. Gut 58(10):1410-1418

16. Al-Sukhni W, Borgida A, Rothenmund H, Holter S, Semotiuk K, Grant R et al (2012) Screening for pancreatic cancer in a high-risk cohort: an eight-year experience. J Gastrointest Surg 16(4):771-783

17. Canto MI, Harinck F, Hruban RH, Offerhaus GJ, Poley JW, Kamel I et al (2013) International Cancer of the Pancreas Screening (CAPS) Consortium summit on the management of patients with increased risk for familial pancreatic cancer. Gut 62(3):339-347

18. Harinck F, Konings IC, Kluijt I, Poley JW, van Hooft JE, van Dullemen HM et al (2016) A multicentre comparative prospective 
blinded analysis of EUS and MRI for screening of pancreatic cancer in high-risk individuals. Gut 65(9):1505-1513

19. Pandharipande PV, Jeon A, Heberle CR, Dowling EC, Kong CY, Chung DC et al (2015) Screening for pancreatic adenocarcinoma in BRCA2 mutation carriers: results of a disease simulation model. EBioMedicine 2(12):1980-1986 